\title{
КРЕАТИВНА ЕКОНОМІКА: ТЕОРЕТИЧНІ ЗАСАДИ ТА ОСОБЛИВОСТІ ЇЇ ФУНКЦІОНУВАННЯ В УМОВАХ СТАНОВЛЕННЯ НОВОЇ ЕКОНОМІКИ
}

\author{
Галина Самойленко \\ КРЕАТИВНАЯ ЭКОНОМИКА: ТЕОРЕТИЧЕСКИЕ ОСНОВЫ \\ И ОСОБЕННОСТИ ЕЕ ФУНКЦИОНИРОВАНИЯ \\ В УСЛОВИЯХ СТАНОВЛЕНИЯ НОВОЙ ЭКОНОМИКИ
}

\author{
Halyna Samiilenko \\ CREATIVE ECONOMY: THEORETICAL FUNDAMENTALS \\ AND FEATURES OF ITS FUNCTIONING IN THE CONDITIONS \\ OF FORMATION OF THE NEW ECONOMY
}

\begin{abstract}
У статті висвітлені питання, що стосуються теоретичних засад формування та функиіонування креативної економіки в умовах становлення нової (постіндустріальної) економіки. 3'ясовано, що креативна економіка є елементом нової економіки та формує ї̈ разом з інноваційною та знаннєвою економікою. Досліджено значення та сутність складових терміна «креативна економіка» та вивчено погляди щодо трактування цієї дефініції закордонними та вітчизняними науковиями, на основі чого виокремлені підходи до сутності ивого поняття та запропоновано його власне розуміння. Розглянуто креативну економіку як системне явище, наведено особливості його функиіонування з погляду системного підходу. Окреслені основні проблеми функиіонування та розвитку креативного сектору економіки, запропоновано иляхи їх вирішення та представлено позитивні наслідки впливу креативної економіки.

Ключові слова: креативна економіка; креативність; нова економіка; креативний процес; креативний сектор економіки; інновачії; креативна діяльність.

Рис.: 3. Табл.: 1. Бібл.: 19.

В статье освещены вопросы, касающиеся теоретических основ формирования и функиионирования креативной экономики в условиях становления новой (постиндустриальной) экономики. Выяснено, что креативная экономика является элементом новой экономики и формирует ее вместе с инновационной экономикой и экономикой знаний. Исследовано значение и сущность составляюших термина креативная экономика и изучены взгляды относительно трактовки этой дефиниции зарубежными и отечественными учеными, на основании чего выделены подходы к сущности этого понятия и предложено его собственное понимание. В статье рассмотрено креативную экономику как системное явление, приведены особенности его функиионирования с точки зрения системного подхода. Очерчены основные проблемы функционирования и развития креативного сектора экономики, предложены пути их решения и представлены положительные последствия воздействия креативной экономики.

Ключевые слова: креативная экономика; креативность; новая экономика; креативный процесс; креативный сектор экономики; инновации; креативная деятельность

Рис.: 3. Табл.: 1. Библ.: 19.

The article covers issues related to the theoretical foundations of the formation and functioning of the creative economy in the conditions of formation of a new (post-industrial) economy.. It has been found that the creative economy is an element of the new economy and shapes it together with the innovation and knowledge economy. The meaning and essence of the components of the term creative economy are studied and the views on the interpretation of the definition by foreign and domestic scientists are studied, on the basis of which the approaches to the essence of this concept are distinguished and its own understanding is offered. The article considers the creative economy as a systemic phenomenon, features of its functioning from the point of view of the system approach. The main problems of functioning and development of the creative sector of the economy are outlined, the ways of their solution are offered and the positive consequences of the influence of the creative economy are presented.
\end{abstract}

Keywords: creative economy; creativity; new economy; creative process; creative sector of economy; innovations; creative activity.

Fig.: 3. Table: 1. References: 19.

JEL Classification: A10; O38

Постановка проблеми. На сучасному етапі функціонування світова економічна система характеризується трансформаційними процесами та становленням постіндустріальної (нової) економіки, що базується на знаннях, інноваціях, інтелектуальних та творчих ресурсах, інформаційних, комунікативних та комп'ютерних технологіях. Такий економічний розвиток набув нових ознак та особливостей, які пов'язані зі зміною факторів виробництва, управлінських методів та підходів, організації бізнес-процесів, характеру та зв'язків між суб'єктами господарювання тощо. На провідні позиції в сучасних умовах

(C) Самійленко Г. М., 2020 
виходять сфери послуг та інноваційна діяльність. Подібні зміни гармонійно пов'язуються 3 глобалізаційними тенденціями та їх успіх залежить від рівня знань, умінь, творчих навичок та інтелектуального розвитку людського капіталу. За умов становлення нової економіки великого значення набуває креативний сектор економіки, який сприяє створенню нових якісних робочих місць, застосуванню новітніх технологій, створенню таких креативних товарів та послуг, які ідентифікують, виокремлюють та роблять привабливішими міста, регіони і навіть країни, а отже, загалом приводять до підвищення конкурентоспроможності, якості життя та соціально-економічного розвитку.

Аналіз останніх досліджень і публікацій. Останнім часом спостерігається активний інтерес щодо становлення та розвитку креативної економіки як з боку закордонних, так і вітчизняних науковців. Засновниками зазначеної концепції сьогодні вважають таких закордонних дослідників, як Дж. Хокінс, Р. Флорида, Ч. Лендрі. Серед вітчизняних науковців, які долучилися до вивчення питань, пов'язаних із формуванням та розвитком креативної економіки, треба виділити таких, як М. Бредіхін, I. Вахович, С. Давимука, А. Євсєєв, А. Пакуліна, Ю. Ушкаренко, Л. Федулова, В. Чорна, О. Чуль тощо.

Такий феномен, як нова економіка: їі сутність, особливості функціонування та розвитку досліджували такі закордонні та вітчизняні дослідники, як Ю. Бажал, В. Геєць, Л. Гронлунд, Е. Ловінс, Л. Ловінс, П. Пільцер, Р. Флемінг, А. Чухно та інші.

Виділення недосліджених частин загальної проблеми. Попри значну кількість наукових робіт із цієї проблеми, не достатньо уваги приділено з'ясуванню місця та ролі креативної економіки на тлі глобалізаційних проявів та на сучасному етапі становлення нової економіки, а також не до кінця розкритими залишаються питання стосовно системного підходу щодо розуміння креативного сектору економіки та виявлення його особливостей.

Мета статті. Мета статті полягає в дослідженні теоретичних основ формування та розвитку креативного сектору економіки в умовах становлення нової економіки, вивченні його сутності та розуміння, а також у з'ясування особливостей функціонування креативної економіки з погляду системного підходу.

Виклад основного матеріалу. Сучасна світова економічна система характеризується трансформацією індустріальної (традиційної) економіки з її прив'язкою до матеріальних ресурсів та домінуванням матеріального виробництва до постіндустріальної (нової) економіки, базою якої є знання, уміння, наукові та технічні досягнення, розробка та впровадження новацій, розвиток інформаційних систем та технологій тощо. Нова економіка - це поняття, що з'явилося в 90 -х роках XX століття з розвитком глобальної мережі Інтернет, інформаційних систем та технологій і у широкому розуміння означає певний прогрес від змін та процесів, які відбуваються в сучасних новітніх умовах господарювання. Нова економіка - це логічний напрям розвитку як глобальних, національних, так і регіональних економіко-господарських систем, який відповідає викликам сучасності. В основі нової економіки лежать знання, ідеї, інформація, інновації та технології, а центральну роль у ній відіграє людина, особистість з ідеєю, знаннями, талантом, креативністю тощо. Особливістю нової економіки слід вважати їі неіндустріальний характер, центричноособистісне спрямування та такі фактори виробництва, як креативний та інтелектуальний потенціал, інтелектуальні ресурси [12].

На тлі функціонування нової економіки з'явилося поняття «креативна економіка», яке характеризує такий напрям розвитку, в центрі якого лежать не матеріальні, а інтелектуальні, творчі ресурси, людський потенціал та їх перетворення та реалізація через створення креативних, оригінальних та неповторних ідей, рішень, проєктів тощо для отримання нових товарів, продуктів, послуг, доходів, успіху, досягнення та підвищення конкурентоспроможності та набуття унікальності. 
ТЕОРЕТИЧНІ ПРОБЛЕМИ РОЗВИТКУ НАЦІОНАЛЬНОЇ ЕКОНОМІКИ

Також нова економіка тісно пов'язана з інноваціями, які є іiі стрижнем, базою, сутністю, провідною характеристикою, що дають поштовх для соціально-економічного розвитку. Не можна не визнати важливість інновацій у сучасних умовах та їхню провідну роль та вплив на функціонування економіки. В економічній літературі сьогодні часто трапляється окреме поняття «інноваційна економіка», під яким у загальному сенсі розуміють економіку, засновану на інноваціях, інформаційних технологіях, позитивному сприйняття та готовності до впровадження нових ідей, розробок, результатом чого $є$ використання отриманої високотехнологічної продукції в усіх секторах та сферах людської діяльності, а також позитивному впливі на суспільний та економічний розвиток [1].

Однією з базових складових нової економіки є знання, продуктивне використання яких сприяє соціально-економічному зростанню та інноваційному розвитку. У постіндустріальних умовах знання виступають фактором сучасного розвитку та є суспільним благом, яке примножується при його використанні. У сучасних наукових джерелах трапляється поняття «знаннєва економіка», яка визначається в загальному розумінні як економіка, що базується на знаннях [3].

Таким чином, креативна економіка, інноваційна економіка та знаннєва економіка $\epsilon$ складовими нової економіки, які тісно перетинаються одна 3 одною та утворюють їі основу (рис. 1). Загалом під новою економікою треба розуміти економіку, яка має постіндустріальний характер та відзначається переходом на нові методи ведення бізнесу, принципи управління та фактори виробництва із застосуванням інформаційних технологій, інновацій, креативності, знань, умінь та навичок, що призводить до посилення ролі нематеріальних активів, креативного потенціалу, людського капіталу та інтелектуальних ресурсів в умовах таких провідних світових економічних тенденцій, як глобалізація та інтеграція.

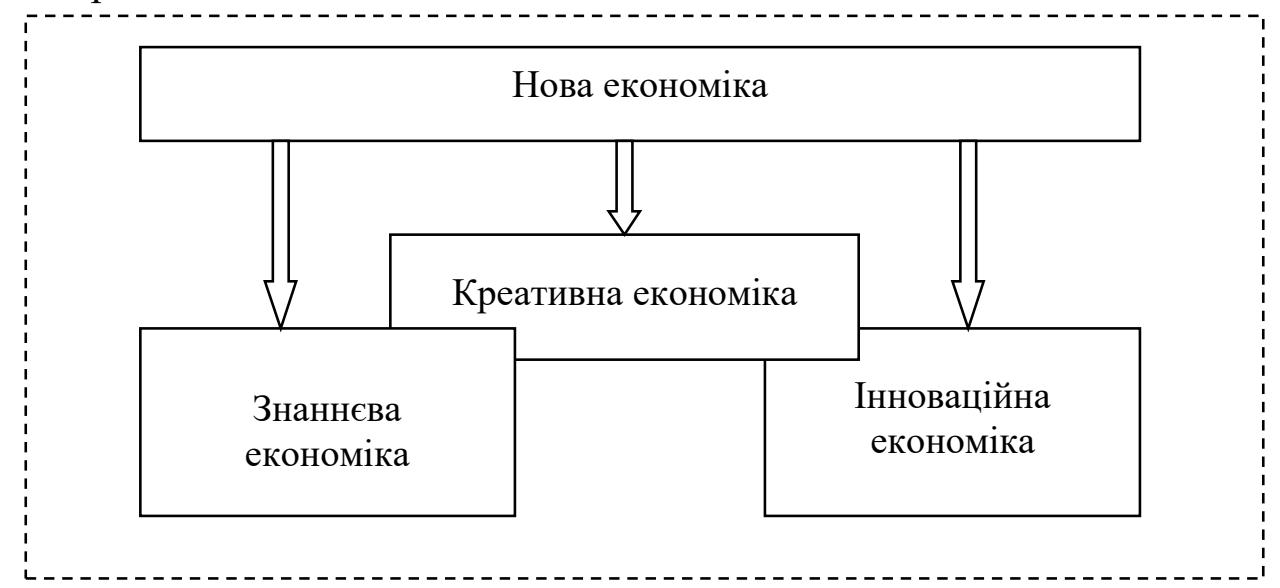

Рис. 1. Основні складові нової економіки

Джерело: розроблено авторкою на основі [2; $3 ; 12]$.

Отже, з огляду на вищевикладене зазначимо, що креативна економіка є складовою нової економіки, сектором швидкого розвитку в сучасних умовах, стратегічним напрямом та сферою діяльності, що забезпечує конкурентоспроможність підприємств (середніх та малих) на основі реалізації креативності та перетворення іiї результатів на функціонуючі бізнеси, які здатні провадити свою діяльність за рахунок власних талантів.

При розгляді поняття та сутності креативної економіки, на нашу думку, слід вивчити значення складових, що утворюють цю дефініцію. Економіка - це багатозначний, багатоаспектний термін, який походить від грецького слова «ойкономія» і в перекладі означає: oikos - будинок, дім; nomos - вчення, закон або «ньому» - регулювати, організовувати. Термін пройшов довгий шлях свого становлення завдяки трансформації економічних формацій, зміні поглядів, підходів, концепцій, теорій тощо. 
У сучасному розумінні термін «економіка» - це господарська діяльність, її організація та управління. При більш детальному дослідженні можна виокремити такі основні значення цього терміна:

- вид, сфера або сектор економічної діяльності певного району, регіону, країни, групи країн або світу;

- сукупність відносин між економічними суб'єктами, які формуються при здійсненні реальної господарської діяльності, сутність якої полягає у виробництві товарів, наданні послуг, їх реалізації, споживанні та розподілі;

- сукупність загальних відносин, які формують наукову дисципліну, що вивчає закони, закономірності та принципи господарської діяльності.

Отже, економіка в загальному сенсі означає економічні відносини між об'єктами господарювання та їх формування та провадження на основі застосування законів, закономірностей та принципів діяльності з урахуванням трансформацій як у світових, так і в регіонально-економічних системах.

Зміни в сучасних економічних системах, у їх відносинах та зв'язках на тлі перманентної нестабільності зовнішнього середовища дедалі більше потребують вміння до них пристосовуватися, створювати та застосовувати щось кардинальне нове, використовуючи креативні підходи, рішення та технології. Термін креативність походить від латинського слова creato - творчість, створення. Тому довгий час поняття креативності та творчості ототожнювалися як закордонними, так і вітчизняними вченими, проте останнім часом з'явилися науковці, які не погоджуються з таким поглядом та пропонують розділити ці терміни $[7$, с. $126 ; 8 ; 15]$. У загальному сенсі під креативністю слід розуміти творчі здібності певної людини, яка має здатність до сприйняття та засвоєння нової інформації, створення новацій завдяки нетривіальному мисленню та нетрадиційному підходу для досягнення поставлених цілей та завдань і вирішення проблем. Таке розуміння креативності приводить до виникнення понять «креативна людина», «креативний індивід» чи «креативна особистість», під якими треба розуміти схильність до всього нового, здатність перетворювати отримані ресурси у процесі нестандартного мислення на основі досвіду, умінь, знань та інтелекту на оригінальні ідеї, рішення, підходи та інновації. Саме на цьому етапі починається креативна діяльність, поступово охоплюючи всі ланки економічних відносин. Зародження креативного процесу відбувається на низовому рівні - у межах окремої особистості, для якої потреба в реалізації генерованих ідей та отриманні від них прибутків стає каталізатором поширення та передачі креативності на наступний рівень - підприємств, а потім на інші - вищі ланки, завершуючись найвищим рівнем - світовою економічною системою, в межах якої формуються креативний сектор, креативна економіка.

Отже, креативний процес, на нашу думку, має декілька рівнів:

- перший - це рівень особистості або окремої людини, яку можна розглядати як систему особистісних якостей індивіда, яка дає можливість генерувати нетривіальні ідеї, уникати стандартних прийомів логіки та мислення, швидко та оригінально досягати поставленої мети, оцінювати ситуацію, вирішувати проблеми та приймати рішення;

- другий - це діяльність на рівні підприємств (мікрорівень): у межах цієї ланки підприємства займаються оформленням креативної ідеї чи рішення та його реалізацією, доведення до споживача з метою отримання прибутку або його примноження;

- третій - це рівень, на якому функціонують різні форми об'єднання підприємств (корпоративні, інтегровані структури, кластери тощо), міста, регіони (мезорівень) - у його межах відбувається акумулювання креативного процесу та його результатів, що пов'язано зі створенням креативних хабів та просторів; 
ТЕОРЕТИЧНІ ПРОБЛЕМИ РОЗВИТКУ НАЦІОНАЛЬНОЇ ЕКОНОМІКИ

- четвертий - рівень держави (макрорівень) - на ньому відбувається формування та розвиток креативних індустрій та національного креативного сектору в межах економічної системи певної держави;

- п'ятий рівень - рівень світової економічної системи (мегарівень) - характеризується формуванням глобальної креативної економіки.

Ефективне функціонування економіки, зокрема й креативної, залежить від успішної реалізації креативного процесу на всіх вищеперерахованих ланках.

Креативна діяльність тісно взаємопов'язана з інноваційним процесом, а 3 погляду послідовності реалізації можна зазначити, що креативність як творчий процес виступає основою, необхідним елементом, передумовою для здійснення інноваційної діяльності.

Креативність можна описати такими ознаками, основними з яких є такі:

- швидкість - кількість інновацій та ідей, які виникають за певний період;

- гнучкість - здатність до швидкого та адекватного реагування на зміни, що впливають на процес вирішення проблем та оперативного виявлення тих осіб, які зможуть їх оригінально здійснювати; готовність та можливість переключатися з однієї ідеї на іншу;

- чутливість - схильність до незвичайних речей, інформації, деталей, невизначеності тощо;

- оригінальність - здатність виробляти нові ідеї, реакції, рішення, які мають відмінності від стандартних;

- критичність - уміння ставити під сумнів будь-яку інформацію, позицію тощо та здатність вчасно ставити питання;

- ризикованість - здатність ризикувати в процесі створення, впровадження та використання інновацій;

- інтегрованість - здатність створювати нові комбінації шляхом поєднання вже відомих складових, які виступатимуть у новій альтернативній якості;

- результативність - наслідок прояву креативності, можливість оцінити залежність результативних показників діяльності суб'єктів господарювання від ступеня нестандартності та незвичності ідей, проєктів, рішень тощо та успішності їх реалізації.

Отже, на основі дослідження вищезазначених понять можна зробити такі висновки щодо креативної економіки:

- по-перше, вона пов'язана з такими видами та секторами економічної діяльності, у яких великого значення набувають знання, креативний талант та критичне мислення як базис для новітніх ідей та рішень;

- по-друге, полягає в набутті нових форм та масштабів, а також у формуванні соціально-економічних зв'язків та відносин між суб'єктами господарювання, що приводить до створення нових товарів та послуг, нових робочих місць, генерування доходів та розвитку міст, регіонів та цілих країн;

- по-третє, полягає в реалізації практичної економічної діяльності на основі новітніх технологій, новацій, а також досягнень людського капіталу (творчих розробок, рішень, ідей, реакцій тощо);

- по-четверте, спирається у своєму функціонуванні та розвитку на постійне оновлення, розширення, примноження вмінь та навичок, на застосуванні інформаційнокомунікаційних та комп'ютерних технологій, у зв’язку з чим потребує залучення висококваліфікованого персоналу.

Поняття «креативної економіки» 3'явилося наприкінці XX століття та почало активно формуватися на початку XXI сторіччя. Генезис креативної економіки наступний:

- 1998 рік - публікація доповіді «Проектування креативної індустрії» Міністерством культури, засобів інформації та спорту Великобританії, в якій містилося визначення креативної індустрії як такої, яка сприяє підвищенню рівня добробуту та збільшенню кількості робочих місць на основі застосування та розвитку креативності, знань та вмінь [17]; 
- 2000 рік - поява дефініції креативна економіка в журналі «Business Week» у статті «The 21-st century corporation: The Creative Economy», в якій було зазначено, що в XXI столітті, великим компаніям та корпораціям для своєї адаптації до умов нової економіки, необхідно враховувати, що основним фактором іiї виробництва $є$ інтелектуальний капітал;

- 2001 рік - вихід книги Дж. Хоккінса «Креативна економіка», в якій автор стверджує про появу нової економіки, яка, змінюючи відносини між підприємництвом та творчістю та поєднуючи їх, буде досягати унікальності та ефективності [13].

При цьому експерти Конференції ООН з питань торгівлі та розвитку під креативною економікою розуміють креативну власність із потенціалом для зростання та розвитку економіки. А в доповіді ЮНЕСКО креативна економіка визначається як один із найбільш швидко зростаючих секторів світового господарства, не лише 3 погляду отримання доходу, а і створення нових робочих місць і збільшення обсягу експортних надходжень [16].

Проте слід зауважити, що наведеним вище етапам становлення та розвитку креативної економіки передували події, які змогли відбутися тільки завдяки застосуванню креативності, створенню нових ідей та рішень, реалізація яких докорінно змінила світовий економічний та соціальний устрій. Серед основних подій треба зазначити такі [19]:

- розробка та створення комп'ютерів, поява яких ознаменувала зародження інформаційної ери;

- поява Інтернету, що призвело до можливості швидко отримувати потрібну інформацію, об'єднувати людей та різні соціальні групи, зробити світ єдиним цілим та започаткувало перехід до глобальної епохи;

- винайдення, запровадження та активне подальше застосування соціальних мереж, що сприяло швидкому спілкуванню та привело до входження людства до комутаційної ери;

- застосування Інтернету та соціальних мереж для комерційних цілей, просування за їх допомогою товарів, послуг і навіть власної особистості; зародження та розвиток електронної комерції та початок диджитал ери.

Усе вищезазначене $є$ результатом застосування та реалізації нових ідей, рішень, проєктів, креативної діяльності, що привело до необхідності грунтовного дослідження теоретичних та практичних аспектів функціонування креативної економіки.

У подальшому вивченням феномену креативної економіки зацікавилися як закордонні, так і вітчизняні вчені, які почали вивчати та представляти свої погляди щодо його розуміння. Отже, поняття креативної економіки сьогодні є відносно новим, проте вже можна виділити певні сформульовані його визначення з різних позицій та поглядів, що наведено в таблиці.

Таблиця

Погляди до розуміння дефініції «креативна економіка»

\begin{tabular}{|l|l|c|}
\hline \multicolumn{1}{|c|}{ Автор } & \multicolumn{1}{|c|}{ Визначення } & Джерело \\
\hline \multicolumn{1}{|c|}{} & \multicolumn{1}{|c|}{2} & \multicolumn{1}{|c|}{} \\
\hline Клоудова Й. & $\begin{array}{l}\text { це економіка, яка заснована на високій концентрації креативної робочої } \\
\text { сили, яка є двигуном інновацій і розробником нових підходів у галузях } \\
\text { науки і досліджень, підприємництва, мистецтва та культури }\end{array}$ & {$[6]$} \\
\hline Федулова Л. & $\begin{array}{l}\text { Креативна економіка грунтується на умовах і факторах генерування інте- } \\
\text { лектуально-прагматичного знання, проривних творчих ідей і винаходів, } \\
\text { на засобах їх ефективної трансформації у високоприбуткові продукти, а } \\
\text { також на талантах, які створюють унікальні ідеї, культурні й матеріальні } \\
\text { цінності }\end{array}$ & {$[2]$} \\
\hline Флоріда Р. & Професійна діяльність у галузі креативної індустрії & {$[18]$} \\
\hline $\begin{array}{l}\text { Чорна В. М., } \\
\text { Бредіхін М. В. }\end{array}$ & $\begin{array}{l}\text { Новий напрям досліджень і практичної діяльності орієнтований на арти- } \\
\text { кульоване з’єднання творчих інновацій і економічної активності суб'єктів }\end{array}$ & {$[14]$} \\
\hline
\end{tabular}


Закінчення табл.

\begin{tabular}{|c|c|c|}
\hline 1 & 2 & 3 \\
\hline $\begin{array}{l}\text { Пакуліна А. А., } \\
\text { Євсеев А. С. }\end{array}$ & $\begin{array}{l}\text { Концепція, яка грунтується на взаємодії між творчістю людини, ідеями, } \\
\text { інтелектуальною власністю, знаннями і технологіями }\end{array}$ & [9] \\
\hline Каменских М. А. & $\begin{array}{l}\text { Концепція, що розвивається та основою якої є креативні активи, за раху- } \\
\text { нок яких здійснюється ріст і розвиток економіки }\end{array}$ & [5] \\
\hline Хокінс Дж. & $\begin{array}{l}\text { Система специфічних соціально-економічних відносин між економікою і } \\
\text { творчим підходом до їі розвитку та удосконалення, що призводить до } \\
\text { становлення нового креативного сектору постіндустріальної економіки, } \\
\text { в основі якого лежить інтенсивне використання творчих та інтелектуаль- } \\
\text { них ресурсів }\end{array}$ & [13] \\
\hline $\begin{array}{l}\text { Степанов А. А., } \\
\text { Савина М. В. }\end{array}$ & $\begin{array}{l}\text { Сукупність специфічних соціально-економічних відносин щодо виробни- } \\
\text { цтва розподілу і споживання, що засновані на нестандартних, нетрадицій- } \\
\text { них, некопійованих ідеях, концепціях, заходах, що забезпечують ефекти- } \\
\text { вне вирішення соціально-економічних проблем на основі нових знань та } \\
\text { принципово якісно нових рішень }\end{array}$ & {$[17]$} \\
\hline Дубина I. Н. & $\begin{array}{l}\text { Сектор національної та світової економіки, в якому виробляються, розпо- } \\
\text { діляються та споживаються продукти та послуги, пов’язані з творчою дія- } \\
\text { льністю (продукуванням і розробкою нових та потенційно значущих ідей) }\end{array}$ & {$[4]$} \\
\hline Головін С. Ю. & Сектор економіки, заснований на різних видах інтелектуальної праці & [10] \\
\hline $\begin{array}{l}\text { Ушкаренко Ю. В., } \\
\text { Чмут А. В., } \\
\text { Синякова К. М. }\end{array}$ & $\begin{array}{l}\text { Концепція постіндустріальної економіки, механізмом функціонування якої } \\
\text { є система специфічних соціально-економічних відносин щодо виробництва } \\
\text { розподілу та споживання благ, що базуються на використанні у ролі факто- } \\
\text { рів виробництва інтелектуального капіталу, креативного потенціалу та та- } \\
\text { ланту породжувати нові оригінальні ідеї, у результаті чого створюється } \\
\text { інноваційний продукт (товар або послуга, наділені економічною цінністю), } \\
\text { або приймаються якісно нові рішення з метою забезпечення потреб }\end{array}$ & [12] \\
\hline
\end{tabular}

На основі наведених у таблиці визначень поняття «креативна економіка» можна зробити такі висновки:

- по-перше, поняття «креативна економіка» порівняно нове та молоде, сформоване нещодавно та перебуває на стадії становлення;

- по-друге, існує досить велика кількість визначень поняття «креативна економіка», що не спрощує, а навпаки ускладнює розуміння зазначеного терміна;

- по-третє, такий стан речей говорить про складність, багатогранність та багатоаспектність терміна «креативна економіка»,

- по-четверте, на основі вивченого різноманіття трактувань вищезазначеного терміна можна виділити такі підходи до його розуміння (рис. 2).

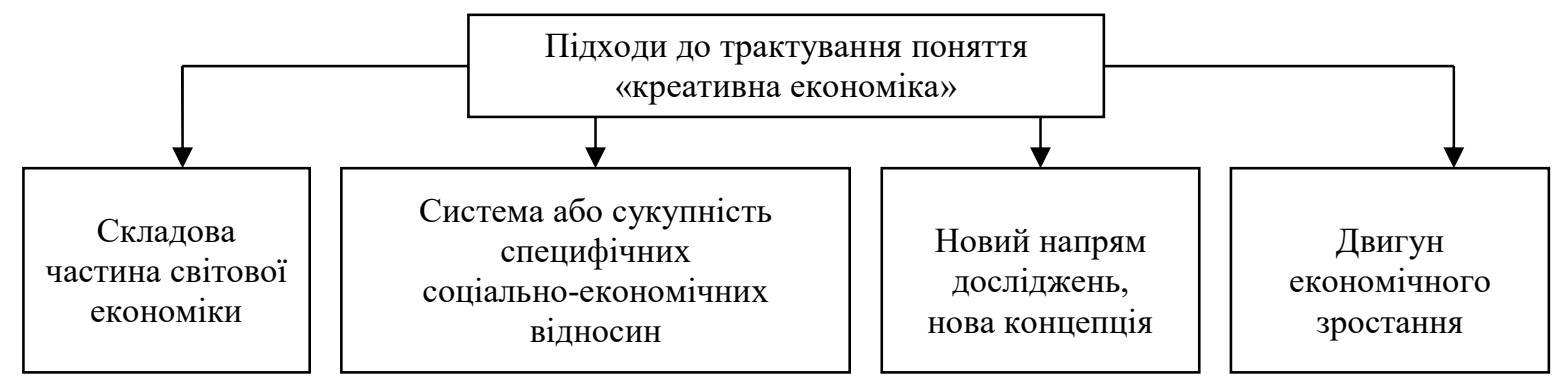

Рис. 2. Підходи до розуміння дефініції «креативна економіка»

Джерело: розроблено авторкою на основі [2-6; 10-14; 18$]$.

Отже, на нашу думку, креативну економіку можна визначити як складову нової (постіндустріальної) економіки, в основі якої $є$ концепція, що грунтується на сукупності специфічних відносин між економічними суб'єктами щодо виробництва, реалізації, споживання та розподілу; функціонування якої потребує творчих ресурсів, знань, інформації для створення нових ідей та цінностей, інновацій, креативної та економічної продукції, що приведе до позитивних економічно-соціальних зрушень. 
Великого значення за цього напряму дослідження набуває розуміння креативної економіки як певного системного явища для з'ясування його принципів та особливостей функціонування і розвитку. Застосування системного підходу до вивчення креативної економіки дає змогу дійти висновку, що вона являє собою складну систему, яка спрямована на реалізацію таких цілей, як підвищення конкурентоспроможності місцевого бізнесу; підвищення якості продукції та послуг; забезпечення зайнятості населення та підвищення iï якості; збільшення доходів до місцевих бюджетів; зменшення рівня відтоку талановитих та креативних людей певної території; активізація туристичної діяльності.

Креативна економіка як системний об'єкт характеризується такими властивостями, як динамічність, гнучкість, адаптивність, відкритість. Розглядаючи креативну економіку з позиції теорії систем, необхідно зазначити, що на неї впливає зовнішнє середовище, під дією якого вона може з часом змінюватися. Його грунтовне вивчення дало змогу виокремити такі фактори формування, зростання та розвитку креативної економіки: людський та інтелектуальний потенціал; попит; рівень доходів споживачів; рівень освіти й компетентності; здатність створювати інфраструктури, які необхідні для повноцінної реалізації знань; творча діяльність усіх суб'єктів ринку; інновації та інвестиції; технологічна, організаційна та інституційна модернізація; наявність відповідних навичок; рівень розвитку громадського сектору; відношення громадських і державних інституцій; наявність великих комерційних структур; наявність закладів вищої освіти.

Креативна економіка як системне явище виконує ряд функцій, а іiї функціонування грунтується на певних принципах (рис. 3).

Зважаючи на вищезазначене, слід виділити такі особливості креативної економіки як системного явища:

- провідне місце новацій у діяльності та сферах, що формують креативу економіку;

- характерний інноваційний розвиток;

- постійна необхідність в отриманні нових знань, створенні ідей;

- суттєвий розвиток інформаційних та комп'ютерних технологій;

- високий відсоток невизначеності у функціонуванні та висока залежність від впливу зовнішнього середовища;

- зміна характеру знань (глобальний та перманентний), постійна потреба в їх перманентному продукуванні;

- перехід та застосування нових методів ведення бізнес-процесів та принципів управління.

На основі проведених досліджень можна сформулювати основні проблеми становлення та розвитку креативної економіки: недосконалість нормативно-правового забезпечення; недостатність, а подекуди відсутність фінансових ресурсів у регіонах та містах; відсутність зацікавленості у здійсненні інновацій в окремі складові креативної економіки - на кшталт культура, спорт, освіта; низький рівень інформованості представників бізнесу, влади тощо відносно перспектив та переваг креативної економіки; відсутність розроблених національних та регіональних програм розвитку креативної економіки; низький відсоток бюджетного фінансування розвитку креативної економіки та iï складових; відсутність застосування регіонального маркетингу щодо формування та розвитку креативної економіки.

Вищезазначені проблеми потребують вирішення, а отже, для успішного функціонування та розвитку креативної економіки необхідна реалізація таких кроків: підняття рівня взаємодії та довіри між економічними суб'єктами, органами влади та населенням; пришвидшення розповсюдження інформаційних потоків між учасниками креативних видів діяльності; забезпечення належних умов для розвитку особистості; виявлення та формування наявного креативного потенціалу в регіонах та містах та надання допомоги в його реалізації; підтримка здатності та вміння як окремих осіб, так і суб'єктів господарювання генерувати нові ідеі, реалізовувати нестандартні проєкти та приймати нетривіальні рішення. 
Принципи створення креативного середовища:

- універсальність креативності;

- свобода дії;

- формування ринків і зв'язків для успішної реалізації ідеї
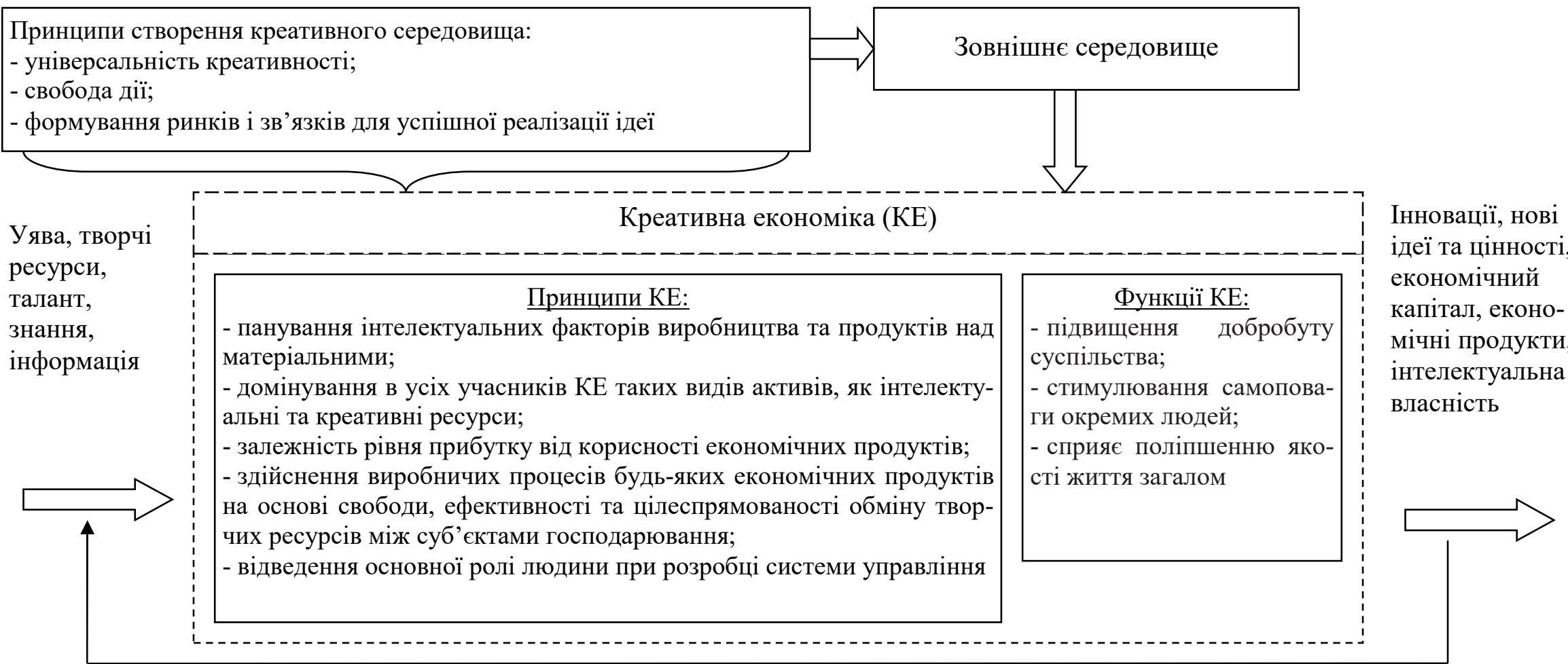

ЗВОРОТНИЙ ЗВ'ЯЗОК

менеджмент: креативний, інноваційний, інвестиційний, виробничий, соціальний

- ідентифікація та брендування міст, регіонів, країн, що сприяє підвищенню їхньої привабливості;

- створення нових робочих місць та підвищення їхньої якості;

- використання новітніх технологій;

- ефективне використання ресурсів, у тому числі природних;

- розвиток та підвищення конкурентоспроможності суб'єктів господарювання

Джерело: розроблено авторкою на основі [1; 2; 7-9; 12-15]. 
Отже, подолання проблем у креативній сфері та реалізація запропонованих заходів щодо їх вирішення призведуть, на нашу думку, до таких позитивних результатів: розвиток малого бізнесу креативного сектору; підвищення рівня інвестиційної та економічної привабливості території, на якій функціонують сектори та види креативної економіки; підвищення якості життя та кваліфікації населення, його культурного й освітнього рівня; підвищення конкурентоспроможності економічних суб'єктів сектору креативної економіки; ефективне використання природноресурсного потенціалу.

Висновки і пропозиції. У статті з'ясовано роль та місце креативного сектору економіки за сучасних умов соціально-економічного розвитку. Виявлено, що креативна економіка $є$ однією з базових складових нової економіки, яка в сучасних умовах перебуває на стадії становлення та сутність якої полягає в застосуванні останніх досягнень, розробок, інновацій, технологій, креативності у своєму функціонуванні, яке супроводжується зміною підходів та принципів до організації та управління бізнес-процесами, сприяє зміцненню та зайнятті ключових позицій нематеріальних факторів виробництва.

Грунтовно вивчено поняття «економіка» та «креативність», з яких утворюється дефініція «креативна економіка», розглянуто їх значення та зміст у сучасних умовах, a також різноманітні погляди закордонних та вітчизняних науковців щодо зазначеної категорії. Проведені дослідження дозволили зробити висновок про існування декількох підходів щодо розуміння цього терміна, а також навести трактування креативної економіки як базового елементу нової економіки, в основі якого $є$ концепція, яка характеризується системою специфічних відносин між суб'єктами господарювання, що перетворює знання, уміння, інформаційні, креативні ресурси тощо в інновації, нові ідеї, проєкти, рішення, економічні та креативні продукти тощо для економічного зростання. Також розглянуто креативну економіку як системне явище, вивчено його зовнішнє середовище, наведено принципи та функції, зворотний зв'язок, вхідні та вихідні параметри, а також описані особливості його функціонування.

\section{Список використаних джерел}

1. Головінов О. М. Інноваційна активність і інноваційні процеси в національній економіці. Економіка та держава. 2013. № 6. С. 4-8.

2. Давимука С. А., Федулова Л. І. Креативний сектор економіки: досвід та напрями розбудови : монографія / ДУ «Інститут регіональних досліджень імені М. І. Долішнього НАН України». Львів, 2017. 528 с.

3. Друкер П. Ф. Эпоха разрыва: ориентиры для нашего меняющегося общества. СанктПетербург : Вильямс, 2007. 323 с.

4. Дубина И. Н. К вопросу о соотношении понятий «Креативная экономика», «Инновационная экономика» и «Экономика знаний». Креативная экономика. 2009. № 6. URL: https://cyberleninka.ru/article/n/k-voprosu-osootnoshenii-ponyatiy-kreativnaya-ekonomikainnovatsionnaya-ekonomika-i-ekonomika-znaniy.

5. Каменских М. А. Теоретико-методические подходы к понятию «креативная экономика» и оценка уровня развития креативной экономики США и России. Экономический анализ: теория и практика. 2013. № 20(323). URL: https://cyberleninka.ru/article/n/teoretiko-metodicheskiepodhody-k-ponyatiyu-kreativnaya-ekonomika-i-otsenkaurovnya-razvitiya-kreativnoy-ekonomiki-sshai-rossii.

6. Клоудова Й. Влияние развития креативной экономики на экономически отсталые регионы. URL: https://core.ac.uk/download/pdf/6476828.pdf.

7. Мержвинська А. М. Дослідження суті креативної економіки та тенденцій і проблем їі розвитку в сучасних умовах. Проблеми системного підходу в економіuі. 2016. Вип. 1(55). С. 125-129.

8. Пакуліна А. А., Бєлоглазова К. В., Пакуліна Г. С. Розвиток креативної економіки в умовах протистоянні глобальній кризі. Економіка та управління начіональним господарством. 2019. Вип. 3(14). С. 76-82. 
ТЕОРЕТИЧНІ ПРОБЛЕМИ РОЗВИТКУ НАЦІОНАЛЬНОЇ ЕКОНОМІКИ

9. Покуліна А. А., Євсєєв А. С. Інноваційна та креативна економіка як умова модернізації національного господарства України. Економіка та управління наиіональним господарством. 2018. Вип. 16. URL: http://www.economyandsociety.in.ua/journal/16_ukr/30.pdf.

10. Словарь психолога-практика / сост. С. Ю. Головин. 2-е изд., перераб. и доп. Москва : ACT, 2001. $308 \mathrm{c}$.

11. Степанов А. А, Савина М. В. Креативная экономика: сущность и проблемы развития. Управление экономическими системами. 2013. № 12 (60). C. 104. URL: http://uecs.ru/marketing/ item/2667-2013-12-26-08-35-52.

12. Ушкаренко Ю. В., Чмут А. В., Синякова К. М. Креативна економіка: сутність поняття та значення для України в умовах європейської інтеграції. Економіка і суспільство. 2018. Вип. 18. C. $67-72$.

13. Хокинс Д. Креативная экономика: как превратить идеи в деньги. Москва : КлассикаXXI, 2011.256 c.

14. Чорна М. В., Бредіхін В. М. Місце креативної економіки в системі відтворення сучасних потреб суспільства. Економічна стратегія і перспективи розвитку сфери торгівлі та послуг. 2016. Вип. 2(24). С. 60-74.

15. Шкарлет С., Дубина М. Особливості взаємодії креативних індустрій та фінансових установ. Проблеми і перспективи економіки та управління. 2019. № 1(17). С. 207-218.

16. Creative Economy Report 2013 by UNESCO. URL: http://www.unesco.org/culture/pdf/ creative-economy-report-2013.pdf.

17. Department for Digital, Culture, Media \& Sport (1998). Creative Industries Mapping Document 1998. URL: https://www.gov.uk/government/publications/creative-industries-mappingdocuments-1998.

18. Florida R. The rise of the Creative Class: And How It's Transforming Work, Leasure, Community and EverydayLife. New York : Basic, 2002.

19. Vdovenko N., Deriy J., Seliverstova L., Kurmaiev P. Formation of the information economy: Organizational and financial aspects. International Journal of Supply Chain Management. 2019. Vol. 8, No 4. Pp. 956-961.

\section{References}

1. Holovinov, O. M. (2013). Innovatsiina aktyvnist $\mathrm{i}$ innovatsiini protsesy $\mathrm{v}$ natsionalnii ekonomitsi [Innovative activity and innovative processes in the national economy]. Ekonomika ta derzhava - Economy and state, 6, pp. 4-8.

2. Davymuka, S. A., Fedulova, L. I. (2017). Kreatyvnyi sektor ekonomiky: dosvid ta napriamy rozbudovy [Creative sector of economy: experience and directions of development]. Dolishny Institute for Regional Studies of the National Academy of Sciences of Ukraine.

3. Druker, P. F. (2007). Jepoha razryva: orientiry dlja nashego menjajushhegosja obshhestva. [The Age of Gap: Landmarks for Our Changing Society]. Viliams.

4. Dubina, I. N. (2009). K voprosu o sootnoshenii poniatii «Kreativnaia ekonomika», «Innovatsionnaia ekonomika» $\mathrm{i}$ «Ekonomika znanii» [On the question of the relationship between the concepts of "Creative Economy", "Innovative Economy" and "Economy of Knowledge"]. Kreativnaia ekonomika - Creative economy, 6. https://cyberleninka.ru/article/n/k-voprosu-osootnoshenii-ponyatiykreativnaya-ekonomika-innovatsionnaya-ekonomika-i-ekonomika-znaniy.

5. Kamenskih, M. A. (2013). Teoretiko-metodicheskie podkhody k poniatiiu «kreativnaia ekonomika» i otsenka urovnia razvitiia kreativnoi ekonomiki SShA i Rossii [Theoretical and methodological approaches to the concept of "creative economy" and assessment of the level of development of the creative economy of the United States and Russia]. Ekonomicheskii analiz: teoriia i praktikaEconomic analysis: theory and practice, 20(323). https://cyberleninka.ru/article/n/teoretikometodicheskie-podhody-k-ponyatiyu-kreativnaya-ekonomika-i-otsenkaurovnya-razvitiya-kreativnoyekonomiki-ssha-i-rossii.

6. Kloudova, J. (2009). Vliianie razvitiia kreativnoi ekonomiki na ekonomicheski otstalye regiony [The impact of the development of the creative economy on economically backward regions]. https://core.ac.uk/download/pdf/6476828.pdf.

7. Merzhvynska, A. M. (2016). Doslidzhennia suti kreatyvnoi ekonomiky ta tendentsii i problem yii rozvytku v suchasnykh umovakh [Research merits creative economy and its problems and trends of development in modern conditions]. Problemy systemnoho pidkhodu v ekonomitsi-Problems of systemic approach in the economy, 1 (55), pp. 125-129. 
8. Pakulina, A. A., Bielohlazova, K. V., Pakulina, H. S. (2019). Rozvytok kreatyvnoi ekonomiky v umovakh protystoianni hlobalnii kryzi [Development of the creative economy in the face of the global crisis]. Ekonomika ta upravlinnia natsionalnym hospodarstvom - Economics and management of the national economy, 3(14), pp. 76-82.

9. Pokulina, A. A., Yevsieiev, A. S. (2018). Innovatsiina ta kreatyvna ekonomika yak umova modernizatsii natsionalnoho hospodarstva Ukrainy [Innovative and creative economy as a condition for modernization of the national economy of Ukraine]. Ekonomika ta upravlinnia natsionalnym hospodarstvom Economics and management of the national economy, 16. http://www.economyandsociety.in.ua/journal/ 16_ukr/30.pdf.

10. Golovin, S. Ju. (Ed.) (2001). Slovar psihologa-praktika [Dictionary of a practicing psychologist]. ( $2^{\text {nd }}$ ed. $)$. AST.

11. Stepanov, A. A, Savina, M. V. (2013). Kreativnaia ekonomika: sushhnost i problemy razvitiia [Creative economy: essence and development problems]. Upravlenie jekonomicheskimi sistemami-Management of economic systems, 12(60), p. 104. http://uecs.ru/marketing/item/2667-2013-12-26-08-35-52.

12. Ushkarenko, Yu. V., Chmut, A. V., Syniakova, K. M. (2018). Kreatyvna ekonomika: sutnist poniattia ta znachennia dlia Ukrainy $\mathrm{v}$ umovakh yevropeiskoi intehratsii [Creative economy: the essence of concept and meaning for Ukraine in conditions of European integration]. Ekonomika $i$ suspilstvo - Economy and society, 18, pp. 67-72.

13. Khokins, D. (2011). Kreativnaia ekonomika: kak prevratit idei $v$ dengi [Creative economics: how to turn ideas into money]. Klassika-XXI.

14. Chorna, M. V., Bredikhin, V. M. (2006). Mistse kreatyvnoi ekonomiky v systemi vidtvorennia suchasnykh potreb suspilstva. [The place of the creative economy in the system of reproduction of modern needs of society]. Ekonomichna stratehiia i perspektyvy rozvytku sfery torhivli ta posluh Economic strategy and prospects for trade and services, 2(24), pp. 60-74.

15. Shkarlet, S., Dubyna, M. (2019). Osoblyvosti vzaiemodii kreatyvnykh industrii ta finansovykh ustanov. [Features of interaction of creative industries and financial institutions]. Problemy i perspektyvy ekonomiky ta upravlinnia - Problems and prospects of economics and management, 1(17), pp. 207-218.

16. Creative Economy Report 2013 by UNESCO. (n.d.). http://www.unesco.org/culture/pdf/ creative-economy-report-2013.pdf.

17. Department for Digital, Culture, Media \& Sport (1998). Creative Industries Mapping Document 1998. https://www.gov.uk/government/publications/creative-industries-mappingdocuments-1998.

18. Florida, R. (2002) The rise of the Creative Class: And How It's Transforming Work, Leasure, Community and EverydayLife. Basic.

19. Vdovenko, N., Deriy, J., Seliverstova, L.,Kurmaiev, P. (2019). Formation of the information economy: Organizational and financial aspects. International Journal of Supply Chain Management, 8(4), pp. 956-961.

Самійленко Галина Миколаївна - кандидат економічних наук, доцент, доцент кафедри менеджменту та державної служби, Чернігівський національний технологічний університет (вул. Шевченка, 95, м. Чернігів, 14035, Україна).

Самойленко Галина Николаевна - кандидат экономических наук, доцент, доцент кафедры менеджмента и государственной службы, Черниговский национальный технологический университет (ул. Шевченко, 95, г. Чернигов, 14035, Украина).

Samiilenko Halyna - PhD in Economics, Associate Professor, Associate Professor of Department of Management and Public Service, Chernihiv National University of Technology (95 Shevchenka Str., 14035 Chernihiv, Ukraine).

E-mail: galinamy@ukr.net

ORCID: https://orcid.org/0000-0001-6844-647X

ResearcherID: V-9327-2018

Самійленко Г. Креативна економіка: теоретичні засади та особливості ії функціонування в умовах становлення нової економіки. Проблеми і перспективи економіки та управління. 2020. № 2 (22). С. 31-42. 